\title{
Temporal Distribution of Blowflies of Forensic Importance (Diptera: Calliphoridae), in Man-Size Domestic Pigs Carcasses, in the Forest Reserve Adolpho Ducke, Manaus, Amazonas, Brazil*
}

\author{
Alexandre Ururahy-Rodrigues ${ }^{1}{ }^{\bowtie}$, José Albertino Rafael ${ }^{1} \&$ José Roberto Pujol-Luz ${ }^{2}$
}

1. Instituto Nacional de Pesquisas da Amazônia - INPA, e-mail: ururahy.rodrigues@gmail.com (Autor para correspondência ${ }^{\bowtie}$ ), jarafael@inpa.gov.br. 2. Universidade de Brasília - UnB, e-mail:.jrpujol@unb.br.

\section{EntomoBrasilis 6 (1): 09-22 (2013)}

Abstract. One of the must forensic importance insect families is Calliphoridae (Diptera) and different species of this family were used to demonstrate the efficiency of the experimental model used in this study. The experiments were performed with domestic pig models (approximately 6o kg) in Adolpho Ducke Forest Reserve (Manaus, Amazonas). To minimize the effect of repeated samplings in the same model (a result of pseudoreplication), two models were used to answer two questions: 1) What is the species composition and temporal distribution of Calliphoridae adults? 2) What is the species composition and temporal distribution of Calliphoridae that effectively colonized the carcass? Six pseudoreplicates were studied in three periods: from 06/30/2005 to 07/30/2005 (less rainy season), from 10/18/2005 to 11/17/2005 (transition period between the two seasons) and from 03/15/2006 to 04/14/2006 (rainy season). The immatures and adults collected were identified as forensic indicators. The decomposition process presented five stages (fresh, bloated, decay, adipocere-like and skeletonization). The first four days included the first three stages of decomposition and were the most attractive to the Calliphoridae. The three taxa that were most abundant, regular and with highest peaks in the first four samples of each experiment were, in ascending order: Hemilucilia semidiaphana (Rondani), Hemilucilia segmentaria (Fabricius) e Paralucilia spp.. Linear regressions showed low values of $\mathrm{F}$ and high values of $\mathrm{P}$, indicating that rain did not influence the sampling results.

Keywords: Calliphorids; Central Amazonia; Forensic Entomology.

\section{Distribuição Temporal de Moscas Varejeiras de Importância Forense (Diptera: Calliphoridae), em Porcos Domésticos, com Massa Corporal Comparável ao de um ser Humano Adulto, na Reserva Florestal Adolpho Ducke, Manaus, Amazonas, Brasil}

Resumo. Uma das famílias de insetos de maior importância forense é Calliphoridae (Diptera). Diferentes espécies dessa família foram utilizados para descrever a eficiência da modelagem experimental aplicada neste estudo. Porcos domésticos foram utilizados como modelos (aproximadamente 6o $\mathrm{kg}$ ), em Manaus, Amazonas, na Reserva Floresta Adolpho Ducke. Para minimizar o efeito das coletas repetidas no mesmo modelo (consequência da pseudoreplicação), foram utilizados simultaneamente dois modelos para responder duas perguntas: 1) Qual a composição e a distribuição temporal dos califorídeos adultos? 2) Qual a composição e a distribuição temporal dos califorídeos que efetivamente colonizaram a carcaça? Foram estudadas seis pseudoréplicas em três períodos: de 30/06/2005 a 30/07/2005 (estação menos chuvosa); de 18/10/2005 a 17/11/2005 (transição entre as duas estações) e de 15/03/2006 a 14/04/2006 (estação mais chuvosa). As táxons coletados nos estágios adulto e imaturo, na carcaça, foram apontadas como indicadoras forenses. O processo de decomposição apresentou cinco estágios: fresco, inchamento, deterioração, saponificação e esqueletização.. Os primeiros quatro dias compreendem os três primeiros estágios do processo de decomposição e foram os mais atrativos para os califorídeos. Os três táxons mais abundantes, regulares e que apresentaram os maiores picos nas quatro primeiras coletas de cada experimento em ordem crescente foram, Hemilucilia semidiaphana (Rondani), Hemilucilia segmentaria (Fabricius) e Paralucilia spp.. Regressões lineares mostraram baixos valores de F e altos de $\mathrm{P}$, indicando que a chuva não influenciou nos resultados das coletas.

Palavras-chave: Amazônia Central; Califorídeos; Entomologia Forense.

]단. orensic entomology is the science that applies knowledge about insects, or other arthropods, to support an investigation in police procedures or prosecutions, through the interpretation of entomological data found in the crime scene that generated such legal proceedings.

In the medico-legal field, the Calliphoridae (Diptera), popularly known as blow flies, can find and colonize animal carcasses usually in a few minutes after death, when that occurs during the day, and is one of the most forensically important families of insects (Oliveira-Costa 2011). Therefore, they are very important organisms for the calculation of postmortem interval (PMI) estimates, which corresponds to the probable time elapsed between death and the discovery of the body, an useful information that can be obtained through the assessment of the period of insect activity on the corpse (PIA). This time can usually be very close to the actual time of death. PMI is calculated based on data from the development time of larvae or pupae, collected on the body or its surroundings, which are reared in the laboratory until the adult emerges (AMENDT et al. 2007).

In Brazil, the application of forensic entomology is not recent, but few publications report the application of entomological data in estimating PMI in criminal investigations: Roquete PinTo (1908) in Rio de Janeiro, Oliveira-Costa \& Mello-Patiu (2004) in Rio de Janeiro, Pujol-Luz et al. (2006, 2008) in Rondônia and Amapá, respectively, and Kosmann et. al. (2011), in Minas Gerais.

*This Research was funded by Conselho Nacional de Desenvolvimento Científico e Tecnológico-CNPq, processes 141747/2004-8 (AUR), 52.1239/95-8 (JAR) and 308636/2007-4 (JRPL) 
Basic entomological forensic studies in the Amazon region are sparse. Half of the published studies aimed at bionomic aspects (Fraga 2004; Oliveira-DA-Silva et al. 2006; Barros-DE-Sousa et al 20012. The other half covered taphonomic and ecological aspects (URURAHY-Rodrigues et al. 2008; Mise et al. 2010; URURAHY-Rodrigues et al. 2010). Studies of community ecology are fundamental to the formation of databases and to point out the best forensic indicators for the Amazon region, as well as for other Brazilian regions.

This study aimed to describe the similarity between the samples based on the composition, abundance and temporal distribution of adults of Calliphoridae throughout the different stages of decomposition of a man-size model and its relation with abiotic variables (temperature, relative humidity and rainfall) Also point the best forensic indicators, by rearing until adults (for identification), the imatures (Larvae) collected. There fore obtaining basic ecological data to one of the most of forensic entomology important dipteran family, in Central Amazonia. The question about similar species, diversity and dominance between the multiple samples, will be discussed in another paper.

\section{MATERIAL AND METHODS}

The research was conducted in "terra firme" upland plateaus with primary forest, in the Adolpho Ducke Forest Reserve $\left(100 \mathrm{~km}^{2}\right)$. The reserve belongs to the National Institute for Amazonian Research (INPA) and is located on the state highway AM-010, Km-26 (o2 55 '51"S, 5958'59”W), Manaus, Amazonas, Brazil.

The models used were large white domestic pigs, with body mass of approximately $60 \mathrm{~kg}$, equivalent to a man-size corpse. The euthanasia of the pigs was performed with a direct shot on the frontal region of the head, using a .38 caliber firearm, to simulate the most common executions (homicides) occurring in Brazil. These proceedings took place in the experimental site between 2:00 and 2:45 pm. At this time (2005-2006), the exigences about ethics permissions were not obrigatory, and ethics comitees were not available in the Amazonas State. In the actual time, projects in execution obtained the permitions for the same euthanasia procedure wich is considered indolor.

The experimental design used six pseudoreplicates in three periods: from 06/30/2005 to 07/30/2005 (less rainy season), from $10 / 18 / 2005$ to $11 / 17 / 2005$ (transition period between the two seasons) and 03/15/2006 to 04/14/2006 (rainy season).

To minimize the effect of repeated samplings in the same model (effect of pseudoreplication) two models were simultaneously used to answer two questions: 1) What is the composition and temporal distribution of species of Calliphoridae adults? 2) What is the composition and temporal distribution of species of Calliphoridae immature (larvae) that effectively colonized the carcass?

The models were protected by galvanized metal frame cages, measuring $4 \mathrm{~m}^{2}$, and covered with wire screens, with a 2 inch mesh (Figures 1 and 2), to avoid disturbance by medium or large vertebrate scavengers. The blow fly adults were captured with a modified suspended trap (RAFAEL \& GoraYEB 1982) (Figure 2). The trap's working principle is to attract and capture flies with the smell of the carcass. Once inside the trap, the flies try to escape through the top where they are captured in a collecting bottle with a pyrethroid tape as killing agent. The models for immature sampling were not covered by any traps and were freely colonized (Figure 1).

Adults were collected daily on the trapped carcasses between 17:30 and 19:00 hours, with a minimum interval of time between the two models. Each sample was transferred to a labeled plastic container $(1 \mathrm{~L})$, and later filled with $80 \%$ ethanol to fix the specimens. The immatures were collected at the same time interval, with at least 30 larvae and/or pupae being collected

per sample, with all morphotypes and life stages observed being sampled. This material was collected with tweezers, on or around the carcass, and placed live in plastic pots containing vermiculite and ground beef with 24 hours of putrefaction, and covered with "organza" to allow ventilation. Each sample was labeled with date and time of the sampling and packaged in rearing cages. After emergence, the adults were pinned or placed in screw cap plastic containers with $80 \%$ alcohol.

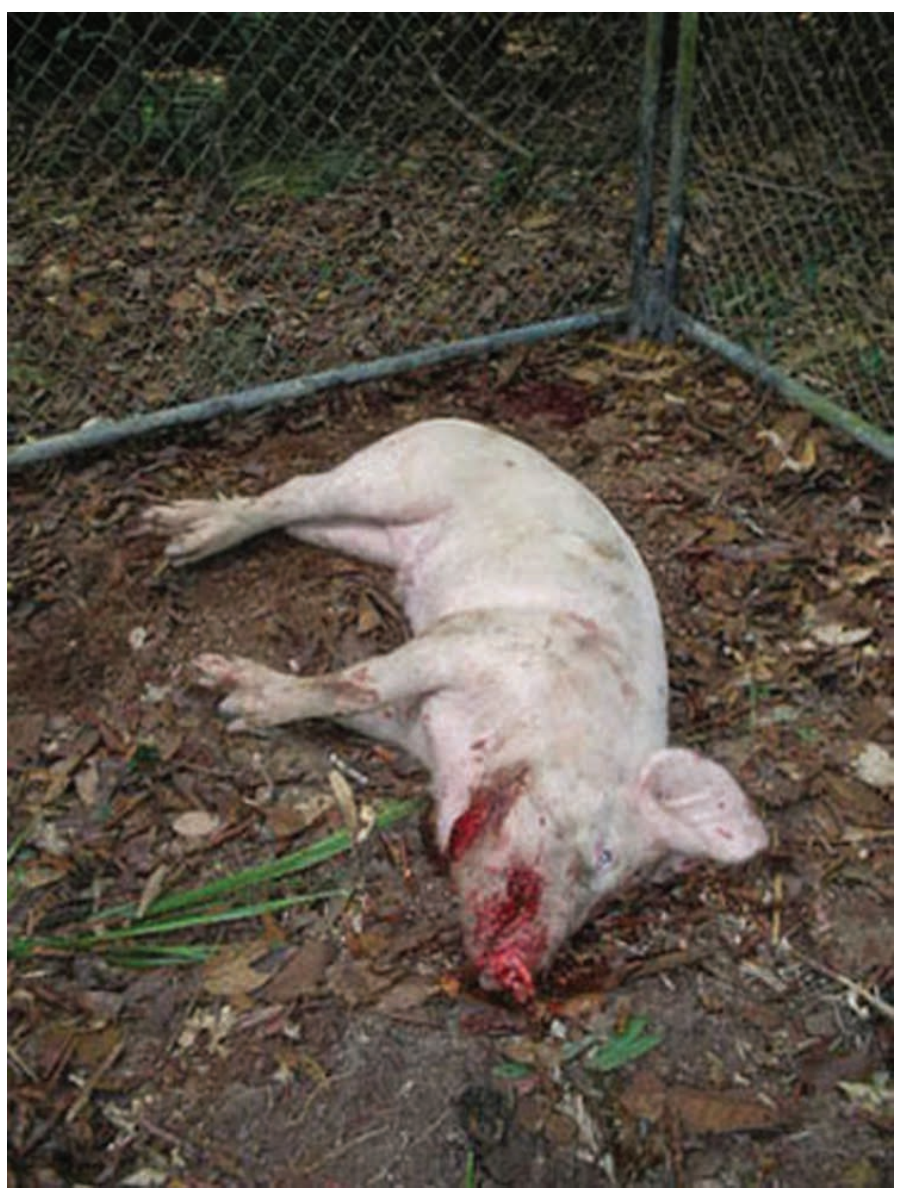

Figure 1. Model in the fresh decomposition stage and used to collect immature and for observations on the decomposition process.

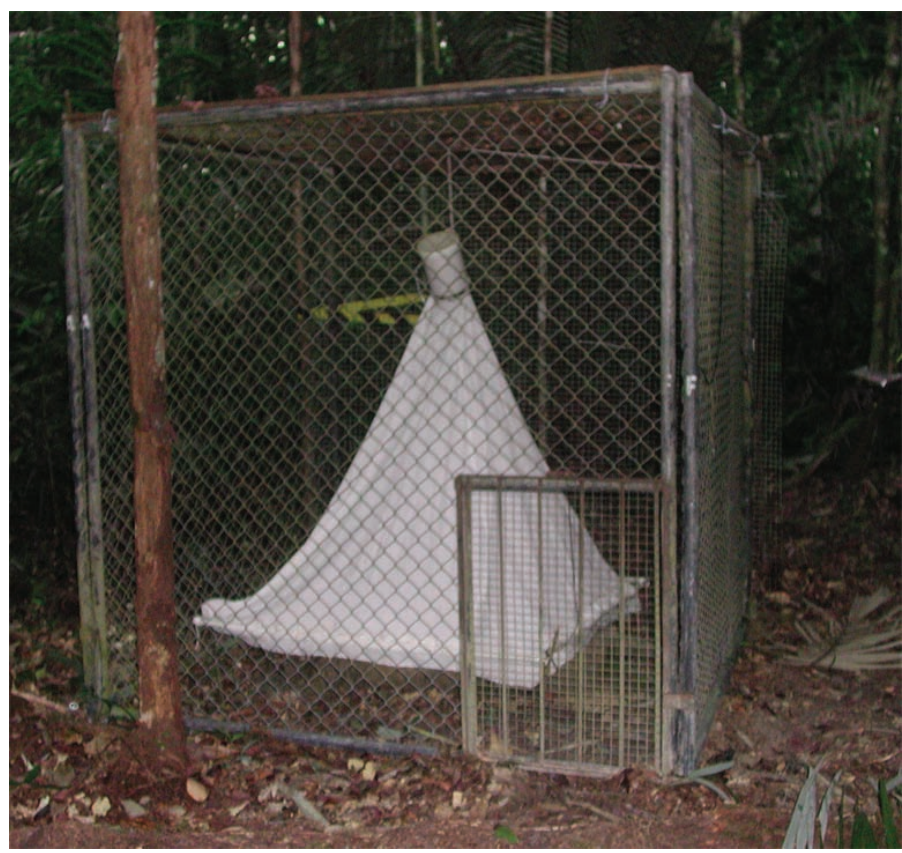

Figure 2. Model used exclusively for collecting adults.

Observations of the decomposition stages were simultaneous to the sampling effort. Field notes and photographs, with a digital camera Olympus Camedia D-435, were made. The rainfall data were obtained from the meteorological station of the forest 
reserve. Additional measurements of temperature and relative humidity were obtained daily in the experimental sites with a digital thermohygrometer (model Gehaka). Decomposition stages were classified using the terminology adopted by (STUART et al. 2005), CATTS \& Haskell (1990) and SMith (1986) to describe the gases in the bloated stage.

The blow flies were identified and quantified based on the works of Mello (1969, 1972, 1996 and 2003) and also with the help of Professor Rubens de Mello (Instituto Oswaldo Cruz, Rio de Janeiro). All material was deposited in the Invertebrate Collection of INPA.

To evaluate the possible influence of abiotic variables on the duration of the decomposition stages, a simple correlation between the independent variables (temperature, relative humidity and precipitation) (Tables 1, 2 and 3) was performed, followed by elimination of more correlated variables (collinears) (MaGnusson \& Mourão 2003). Next, a linear regression was performed between the duration of stages of decomposition and the less collinear variable.

To evaluate the similarity between samples, considering the composition and abundance of species, a indirect polar ordering through a non-metric multidimensional scaling (NMDS) (MacCune \& Grace 2002; Magnusson \& Mourão 2003) was performed, using the Bray-Curtis distance and based on the relative abundance data (Tables 4,5 and 6). Next, the data were analyzed with a simple linear regression between the derived ordination axes with the less collinear variable and the postmortem interval (720 hours).

To evaluate the duration of decomposition stages over the three periods studied and its influence on the composition and abundance of species of blow flies, a simple discriminant analysis was performed between the duration of stages converted into categories of time and the axes of the composition ordination (MDS1 + MDS2 + decomposition stages).

To evaluate the differences between the sampling of adults and immatures the list of species obtained in the two sampling efforts were qualitatively compared. Species that had adult and immature stages effectively colonizing the carcass were determined as forensic indicators. Statistical analyzes and graphs were generated through the program PAST 1.81 (HARPER \& RYAN 2008) and SYSTAT 11 (Systat Software Inc. SSI).

\section{RESULTS AND DISCUSSION}

Why use pseudoreplicates and not replicates? The published Brazilian studies on forensic ecological communities, that used domestic pigs as models, also used pseudoreplicates (CARVAlHo et al. 2000; CARVAlHo et al. 2001, 2004; MARChiori et al. 2000; Oliveira-DA-Silva et al. (2006); URURAHY-Rodrigues et al. 2008, 2010; BARBosa et al. 2010; BiAvati et al. 2010; Mise et al. 2010).

The use of replicates in forensic taphonomic studies are unfeasible due to logistical problems: If an experiment with a $60 \mathrm{~kg}$ pig must last 60 days for the carcass to reach the remains stage, it would be necessary to have 60 temporal replicates that need to be spatially replicated at least three times. This imagined experiment would need 180 pigs of $60 \mathrm{~kg}$ for just one seasonal period. If this reasoning is applied to a study of the decomposition processes and necrophagous entomofauna in the Amazon, comparing summer and winter season, it would take 360 pigs of $60 \mathrm{~kg}$. For example, just for one experiment in the summer 180 pigs would have to be killed with a shot in the head at the same time by 180 armed men. In the second (winter) experiment, the same process would have to be done again. Since it would be extremely problematic using replicates, pseudoreplication was chosen instead. However, a new experimental design was created, aiming to minimize the effects of repeated measurements on the same model (influence of pseudoreplication).

Species composition of collected Calliphoridae adults and immatures. Ten adult taxa and three immature taxa were collected and are presented in box 1 . As expected, the collected taxa differ from those found in studies conducted in urban areas in other Brazilian regions. Species with a low synanthropic index (preference for areas with human interference) as Hemilucilia segmentaria (Rondani), Hemilucilia semidiaphana (Fabricius) and species of the genera Paralucilia were dominant in abundance and were most efficient in colonizing the carcasses. A total of 35,751 adult Calliphoridae were collected in the three periods studied, 14.933 in the less rainy season (41.7\% of total), 11.098 in the transition period (31.04\% of total) and 9720 in the rainy season (27.18 \% of total). There was a gradual and low reduction of total abundance and percentage of blow flies collected in the three experiments.

Box 1. Species composition of adult Calliphoridae collected. The taxa marked in gray strong were collected as larvae, reared until adult emergence and were pointed as forensic indicators.

\begin{tabular}{|l|}
\hline Chrysomyinae (1), Mesembrinellinae (2) e Calliphorinae (3). \\
1- Hemilucilia segmentaria (Fabricius). Neotropical. \\
1- Hemilucilia semidiaphana (Rondani). Neotropical. \\
1- Paralucilia spp. Neotropical. \\
1- Hemilucilia souzalopesi (Mello). Neotropical. \\
1- Chloroprocta idioidea (Robineau-Desvoidy). Neotropical. \\
1- Chrysomya megacephala (Fabricius). Cosmopolite. \\
1- Chrysomya albiceps (Wiedeman).Cosmopolite. \\
1- Cochliomyia macellaria (Fabricius). Neartic e Neotropical. \\
2- Mesembrinella bellardiana Aldrich. Neotropical. \\
2- Eumesembrinella besnoiti (Seguy). Neotropical. \\
3- Phaenicia eximia (Wiedemann). Neartic and Neotropical. \\
\hline
\end{tabular}

Stages of decomposition observed and their characteristics. Five stages of decomposition were noted:

\section{Fresh (Figure 1)}

This sage was characterized by physical signs in the appearance of the corpse as hypostasis (deposition of blood in the lower parts due to gravity), rigor mortis (stiffening of the limbs due to dehydration, anaerobic glycolysis, coagulation of myosin and the accumulation of acid) and "Posthumous Brouardel Circulation" (peripheral blood vessels are pressured from inside out by internal gas pressure and are visible under the skin, giving a varicose aspect, showing the first signs of body swelling). This stage's duration did not change in the three experiments and lasted about a day. It is probably due to the little temperature variation throughout the year in the region.

Bloated (Figure 3). Characterized by a strong odor, rigor mortis completely settled, distinct hypostasis, presence of a "green abdominal spot", anal and tongue protrusion, and bloating of the model into the "fighter position" as described by OliveiraCosta (2011). The bloating occurs due to the putrefaction gases which, according to SмIтH (1986), are mainly ammonia $\left(\mathrm{NH}_{3}\right)$, hydrogen sulfide $\left(\mathrm{H}_{2} \mathrm{~S}\right)$, carbon dioxide $\left(\mathrm{CO}_{2}\right)$ and nitrogen $\left(\mathrm{N}_{2}^{3}\right)$. The bloated stage lasted two days and did not vary during the less rainy season and the transition period. However, in the rainy season it lasted about a day.

Decay (Figure 4). Characterized by rupture of the decomposing tissue (due to internal gas pressure), end of rigor mortis, wilting of the models and the release of exudates (fluids from dehydration, lysis of proteins and lipids, cellular necrosis, etc.). Its duration did not vary in the three experiments, lasting about a day. However, during the rainy season it started one day earlier. 
Adipocere (Saponification) (Figure 5). This decomposition stage was characterized by a preservation of the carcasses for a few days in the less rainy season and in the transition period, but was not the case in the rainy season. The saponification or adipocere is an unusual stage of decomposition, difficult to be observed and is usually associated with long postmortem intervals, as observed by Moura et al. (1997) in studies with rats in Parana, Brazil. Adipocere occurrence may be directly linked with high relative humidity in association with alkaline soils (Oliveira-Costa 2011), a situation which is compatible with the experimental sites of the current study. In the saponification process triglycerides suffer hydrolysis and hydrogenation, by the action of endogenous lipolytic enzymes or by enzymes secreted by bacteria, which convert fats into soap (STUART et al. 2005). This process preserves the corpse, especially and more easily, in cases where there is mechanical obstruction to the scavenger's actions, when the corpse was buried.

Skeletonization (Figure 6). This decomposition stage was characterized by progressive loss of body mass and increase of skeleton exposure, especially with the full skeletonization of the head, extremities, ribs, sternum, and pelvic and scapular girdles. This is due to the feeding activity of necrophagous insect larvae (mainly Calliphoridae). Its duration varied in the rainy season, which was when this stage started a day earlier. The thirty days of observations were not sufficient for a complete skeletonization of the models. None of the models reached the stage of remains, as observed by other authors in studies with models with lower body mass. This shows that data generated by experiments with models with lower body mass can not be extrapolated for adult humans.

Correlation between the abiotic variables (temperature, relative humidity and rainfall) and the possible influence of these variables over the stages of decomposition (Tables 1, 2 and 3).

Temperature $\mathbf{x}$ Rainfall (Pluviometric precipitation). The linear correlation test of Pearson was not statistically significant between temperature and precipitation, indicating a negative correlation of about $25.4 \%(\mathrm{r}=-0.25402, \mathrm{p}=0.132)$, demonstrating that there is a slight tendency for the less rainy season to be warmer and the other two periods to be cooler due to increase in precipitation.

Relative humidity (RH) $x$ Rainfall (Pluviometric precipitation). The linear correlation test of Pearson was not statistically significant between relative humidity and rainfall, indicating positive correlation of about $25.9 \%(r=0.259567$, $\mathrm{p}=0.0092)$, demonstrating that the two variables increase together and that the rainy season and the transition period had a bit higher values of precipitation and relative humidity when compared to the less rainy season.

Temperature $\mathbf{x}$ Relative humidity (RH). The linear correlation test of Pearson was statistically significant between temperature and relative humidity, and had a negative correlation, about $48 \%(\mathrm{r}=-0.48164, \mathrm{p}=0.0001)$, demonstrating that an increase in temperature and decrease in $\mathrm{RH}$ are correlated. A comparison between the correlation coefficients (temperature, relative humidity and precipitation) found that the less correlated variable among the three was precipitation, so the formers were eliminated for presenting collinearity.

Rainfall (Pluviometric precipitation) and its possible influence in the decomposition stages. To check the influence of precipitation on the duration of the decomposition stages, a linear regression was performed between the duration of the stages that showed variation and the precipitation (Tables 1,2 and 3 ).

The fresh stage lasted about a day in all three experiments, thus

the regression analysis was not necessary. In the rainy season there was less precipitation during the fresh stage, however in transition period and in rainfall the opposite occurred and the recorded values were 2 and $0.8 \mathrm{~mm}$, respectively.

The duration of the bloated stage did not vary comparing the rainy season and the transition period. The bloated stage started after the first day of IPM and it lasted for about two days, which was not the same for the rainy season, when it lasted for about a day. However, linear regression analysis was not significant for the influence of rainfall in this variation $(\mathrm{F}=0.063, \mathrm{df}=1,88$ and $\mathrm{p}=0.803$ ).

The duration of the decay stage did not vary in all the three experiments and it lasted for about a day, like in the fresh stage. However, its start in the rainy season was anticipated in one day and took place in the third day after death. During this stage, it only rained during the transition $(4.8 \mathrm{~mm})$. Regression analysis was not significant for the influence of precipitation on the variation $(\mathrm{F}=0.103 ; \mathrm{GL}=1,88$ and $\mathrm{p}=0.750)$.

The adipocere stage started on the fifth day after death in the less rainy season and the transition period, and it lasted 8 days. However, this stage did not happen in the rainy season and gave place to skeletonization. Regression analysis was not statistically significant for the influence of precipitation on the variation $(\mathrm{F}=$ 0.096; GL = 1, 88, p = 0.757).

The skeletonization stage took place on the fourteenth day postmortem in the less rainy season and the transition period, and remained in progression until the last observations done on the models. In the rainy season, its start was anticipated and replaced the saponification stage, starting on the fifth day after death and still going on until the last observations were done on the models. Regression analysis was not significant for the influence of precipitation on the variation $(\mathrm{F}=1.205 ; \mathrm{GL}=1,88$ and $\mathrm{p}=0.275)$.

Relation between the temporal distribution of adult Calliphoridae (NMDS axes) composition and abundance with precipitation, postmortem interval (24-720 hours) and the decomposition stages

Similarities and dissimilarities between the samples (1-90) while considering the composition and abundance of species (Tables. 4, 5 and 6) (Figure 7). The polar indirect ordination (Non-metric Multidimensional Scaling (NMDS) based on Bray-Curtis distance) (Tables 4, 5, 6) (Figure 7) left as nearest the first five samples of the three experiments. These early samples have the largest similarity distances in relation to the others, demonstrating that the first five days of decomposition presented the greatest richness and abundance of species. The first five days cover the first stages of decomposition (fresh, bloated, decay and the first day of saponification, when it occurs), which were the most attractive to the blow fly species. The remaining samples shared a decrease in abundance and taxa, but also presented secondary lower peaks of abundance, which can be interpreted as recurrence of species, and may be related to recent emerged adults of the trapped first generation of colonizing blow flies.

Relationship between the ordination of the composition and abundance of adult blow flies (NMDS axes) with the rainfall (Figures 8 and 9). To evaluate the influence of rainfall on the abundance of the taxa collected, simple's linear regressions were performed between this variable and the two resulting ordination axes (NMDS1 and NMDS2). The analyses results were not statistically significant to the axis NMDS1 $(\mathrm{F}=$ $0.971, \mathrm{df}=1,88$ and $\mathrm{P}=0.327)$ and the axis NMDS2 $(\mathrm{F}=6.749$, $\mathrm{df}=1,88$ and $\mathrm{P}=0.011$ ). The low $\mathrm{F}$ values and high $\mathrm{P}$ values suggest that the rain did not influence the resulting samples (Figures 9.10). 


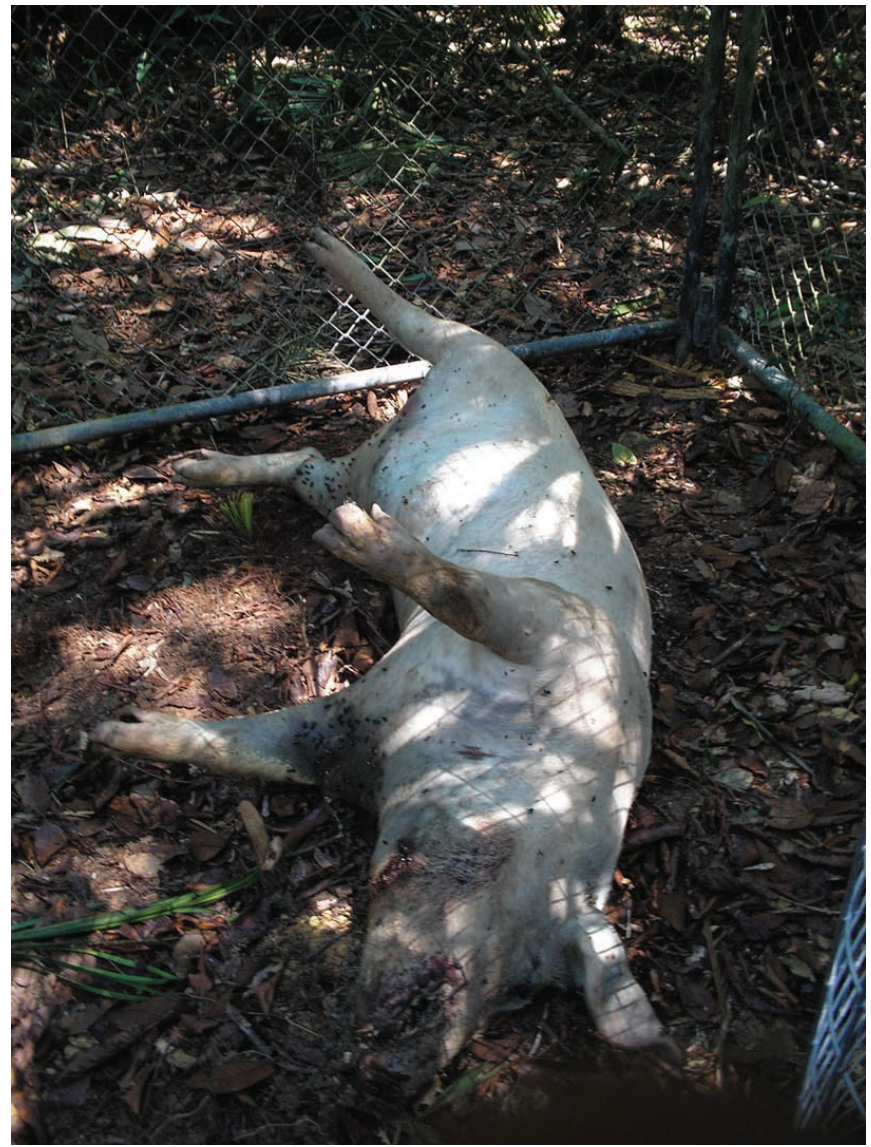

Figure 3.Model in the bloated decomposition stage.

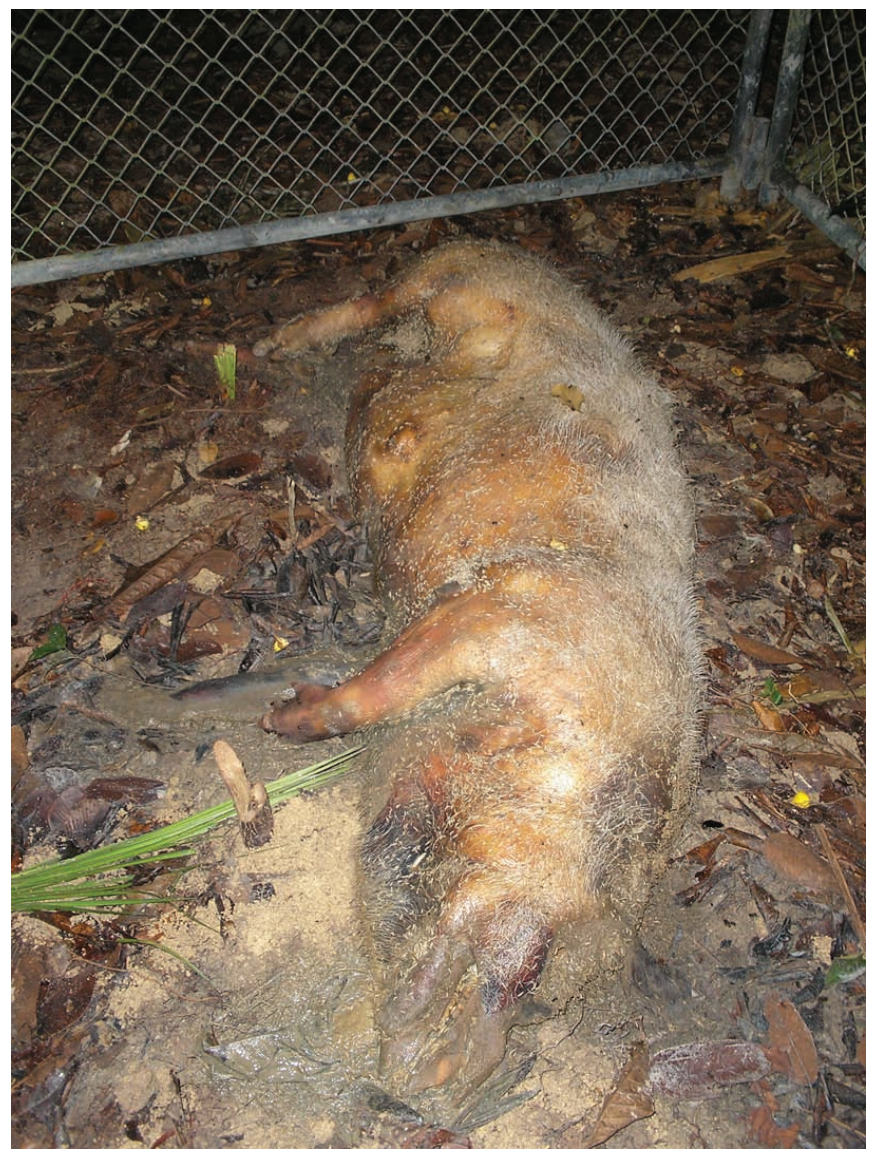

Figure 5. Model in the adipocere decomposition stage.

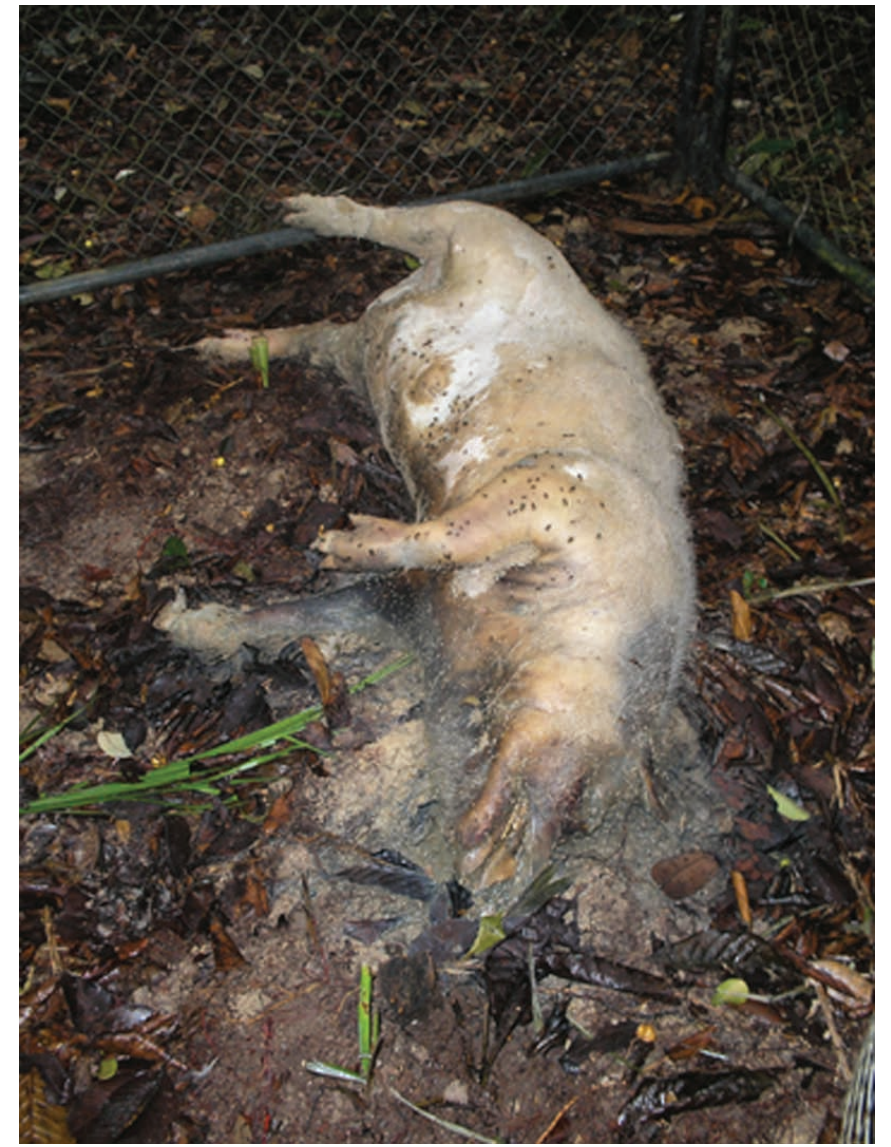

Figure 4. Model in the decay decomposition stage.

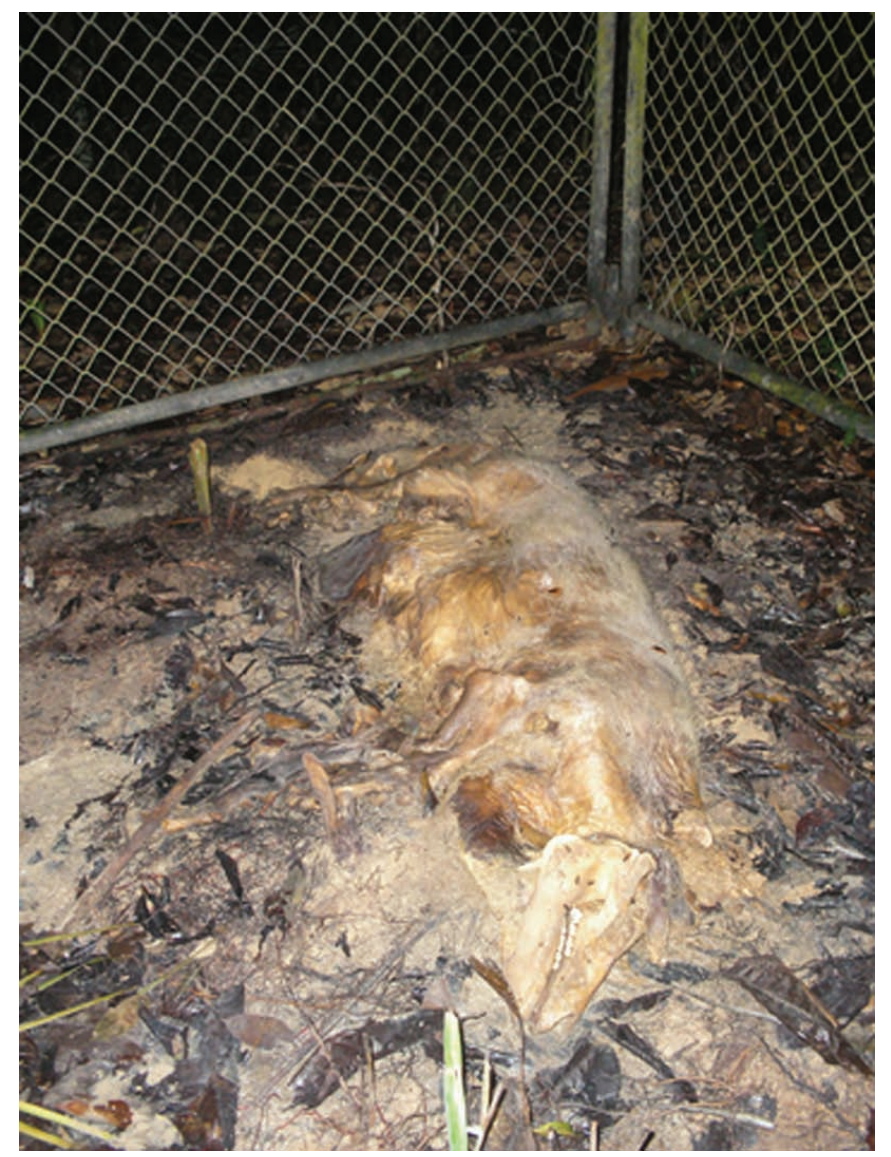

Figure 6. Model in the skeletonized decomposition stage.

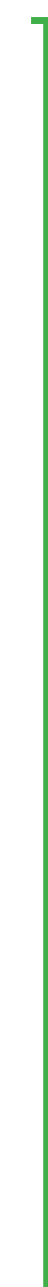


Table 1. Date, samples, Postmortem interval in hours, temperature, rainfall, relative humidity and the duration of decomposition stages in hours in the less rainy season. PMI, postmortem interval; Temp: temperature; RH: relative humidity; FR: fresh: BL: Bloated; DE: Decay; AD: Adipocere and SK: skeletonization.

\begin{tabular}{|c|c|c|c|c|c|c|c|c|c|c|}
\hline Date & Samples & IPM & Temp & Rainfall & RU & FR & BL & DE & AD & SK \\
\hline 1/7/2005 & 1 & 24 & 25.2 & 14.7 & 85 & 24 & o & o & o & o \\
\hline 2/7/2005 & 2 & 48 & $25 \cdot 3$ & 6.4 & 83 & o & 24 & o & o & o \\
\hline 3/7/2005 & 3 & 72 & $25 \cdot 3$ & 15.5 & 93 & o & 48 & o & o & o \\
\hline $4 / 7 / 2005$ & 4 & 96 & 27 & o & 83 & o & o & 24 & o & o \\
\hline $5 / 7 / 2005$ & 5 & 120 & 24.9 & o & 83 & o & o & o & 24 & o \\
\hline $6 / 7 / 2005$ & 6 & 144 & 25 & $5 \cdot 3$ & 83 & o & o & o & 48 & o \\
\hline 7/7/2005 & 7 & 168 & 26.2 & o & 82 & o & o & o & 72 & o \\
\hline $8 / 7 / 2005$ & 8 & 192 & $25 \cdot 3$ & o & 77 & o & o & o & 96 & o \\
\hline 9/7/2005 & 9 & 216 & $25 \cdot 5$ & o & 80 & o & o & o & 120 & o \\
\hline $10 / 7 / 2005$ & 10 & 240 & 26.2 & o & 81 & o & o & o & 144 & o \\
\hline $11 / 7 / 2005$ & 11 & 264 & 24.2 & 68.3 & 90 & o & o & o & 168 & o \\
\hline $12 / 7 / 2005$ & 12 & 288 & 24.1 & 0.8 & 91 & o & o & o & 192 & o \\
\hline 13/7/2005 & 13 & 312 & 24.7 & o & 91 & o & o & o & o & 24 \\
\hline $14 / 7 / 2005$ & 14 & 336 & 25.5 & o & 84 & o & o & o & o & 48 \\
\hline $15 / 7 / 2005$ & 15 & 360 & 26.8 & o & 82 & o & o & o & o & 72 \\
\hline $16 / 7 / 2005$ & 16 & 384 & 26.8 & o & 78 & o & o & o & o & 96 \\
\hline 17/7/2005 & 17 & 408 & 26.1 & o & 76 & o & o & o & o & 120 \\
\hline $18 / 7 / 2005$ & 18 & 432 & 28.3 & o & 74 & o & o & o & o & 144 \\
\hline 19/7/2005 & 19 & 456 & 27.1 & o & 73 & o & o & o & o & 168 \\
\hline $20 / 7 / 2005$ & 20 & 480 & 26.2 & o & 72 & o & o & o & o & 192 \\
\hline 21/7/2005 & 21 & 504 & 24.9 & o & 81 & o & o & o & o & 216 \\
\hline
\end{tabular}

Table 2. Date, samples, postmortem interval in hours, temperature, rainfall, relative humidity and the duration of decomposition stages in hours in the intermediate period. PMI, postmortem interval; Temp: temperature; RH: relative humidity; FR: fresh: BL: Bloated; DE: Decay; AD: Adipocere and SK: skeletonization.

\begin{tabular}{|c|c|c|c|c|c|c|c|c|c|c|}
\hline Date & Samples & IPM & Temp & Rainfall & RU & FR & BL & DE & AD & SK \\
\hline 19/10/2005 & 31 & 24 & 27 & 0.5 & 98 & 24 & o & o & o & o \\
\hline 20/10/2005 & 32 & 48 & 26.6 & o & 74 & o & 24 & 0 & o & o \\
\hline 21/10/2005 & 33 & 72 & 27.4 & o & 82 & o & 48 & o & o & o \\
\hline $22 / 10 / 2005$ & 34 & 96 & 24.6 & 4.8 & 89 & o & o & 24 & o & o \\
\hline $23 / 10 / 2005$ & 35 & 120 & 26 & o & 82 & o & o & o & 24 & o \\
\hline $24 / 10 / 2005$ & 36 & 144 & 27.1 & o & 81 & o & o & o & 48 & o \\
\hline $25 / 10 / 2005$ & 37 & 168 & 25.8 & 0.5 & 82 & o & o & o & 72 & o \\
\hline $26 / 10 / 2005$ & 38 & 192 & 26.6 & o & 82 & o & 0 & o & 96 & 0 \\
\hline 27/10/2005 & 39 & 216 & 24.8 & 0.5 & 81 & o & o & o & 120 & o \\
\hline $28 / 10 / 2005$ & 40 & 240 & 28.3 & o & 81 & o & o & o & 144 & o \\
\hline 29/10/2005 & 41 & 264 & 28.8 & o & 79 & $\mathrm{O}$ & o & o & 168 & o \\
\hline $30 / 10 / 2005$ & 42 & 288 & 28.6 & 27.9 & 77 & 0 & 0 & 0 & 192 & 0 \\
\hline $31 / 10 / 2005$ & 43 & 312 & 29 & o & 71 & o & o & o & 0 & 24 \\
\hline $1 / 11 / 2005$ & 44 & 336 & 29.8 & 0 & 69 & o & o & o & o & 48 \\
\hline $2 / 11 / 2005$ & 45 & 360 & 25.8 & $3 \cdot 3$ & 73 & $\mathrm{o}$ & o & 0 & o & 72 \\
\hline $3 / 11 / 2005$ & 46 & 384 & $25 \cdot 3$ & 33 & 83 & o & o & o & o & 96 \\
\hline 4/11/2005 & 47 & 408 & 26.1 & o & 80 & o & o & o & o & 120 \\
\hline $5 / 11 / 2005$ & 48 & 432 & 23 & 55.6 & 84 & 0 & 0 & 0 & o & 144 \\
\hline $6 / 11 / 2005$ & 49 & 456 & 23.8 & 19.8 & 78 & o & o & o & o & 168 \\
\hline 7/11/2005 & 50 & 480 & 24.6 & o & 75 & 0 & 0 & o & o & 192 \\
\hline $8 / 11 / 2005$ & 51 & 504 & 25.4 & o & 73 & o & o & o & o & 216 \\
\hline $9 / 11 / 2005$ & 52 & 528 & 23.2 & 1.8 & 78 & o & o & o & o & 240 \\
\hline 10/11/2005 & 53 & 552 & 25.1 & o & 80 & o & o & o & o & 264 \\
\hline 11/11/2005 & 54 & 576 & 28.5 & 0 & 80 & 0 & 0 & 0 & 0 & 288 \\
\hline $12 / 11 / 2005$ & 55 & 600 & 26 & 10.7 & 81 & o & o & o & o & 312 \\
\hline 13/11/2005 & 56 & 624 & 27.5 & 10.7 & 83 & o & o & o & o & 336 \\
\hline 14/11/2005 & 57 & 648 & 26.7 & 782 & 82 & 0 & o & o & o & 360 \\
\hline 15/11/2005 & 58 & 672 & 27.1 & 15.2 & 86 & 0 & 0 & 0 & o & 384 \\
\hline 16/11/2005 & 59 & 696 & $25 \cdot 3$ & 43.2 & 89 & 0 & 0 & o & o & 408 \\
\hline $17 / 11 / 2005$ & 60 & 720 & $27 \cdot 3$ & 0.5 & 90 & 0 & o & o & o & 432 \\
\hline
\end{tabular}


Table 3. Date, samples, postmortem interval in hours, temperature, rainfall, relative humidity and the duration of decomposition stages in hours in the rainy season. PMI, postmortem interval; Temp: temperature; RH: relative humidity; FR: fresh: BL: Bloated; DE: Decay; AD: Adipocere and SK: skeletonization.

\begin{tabular}{|c|c|c|c|c|c|c|c|c|c|c|}
\hline Date & Samples & IPM & Temp & Rainfall & RU & FR & BL & DE & AD & SK \\
\hline $16 / 3 / 2006$ & 61 & 24 & 23.4 & 34.5 & 99 & 24 & o & o & o & o \\
\hline 17/3/2006 & 62 & 48 & 24 & 12.4 & 95 & o & 24 & o & o & o \\
\hline 18/3/2006 & 63 & 72 & 26.9 & o & 88 & o & o & 24 & o & o \\
\hline $19 / 3 / 2006$ & 64 & 96 & 27.6 & o & 90 & 0 & o & 0 & 0 & 24 \\
\hline $20 / 3 / 2006$ & 65 & 120 & 25.9 & 7.6 & 95 & 0 & o & o & o & 48 \\
\hline $21 / 3 / 2006$ & 66 & 144 & 25.1 & 8.1 & 93 & o & o & o & o & 72 \\
\hline $22 / 3 / 2006$ & 67 & 168 & $25 \cdot 7$ & 29.2 & 97 & o & o & o & o & 96 \\
\hline $23 / 3 / 2006$ & 68 & 192 & 25 & 11.2 & 97 & o & o & o & o & 120 \\
\hline 24/3/2006 & 69 & 216 & 24.4 & 29.5 & 97 & o & o & o & o & 144 \\
\hline $25 / 3 / 2006$ & 70 & 240 & 24.4 & 2.8 & 96 & o & o & o & o & 168 \\
\hline $26 / 3 / 2006$ & 71 & 264 & 24.2 & 6.9 & 99 & o & o & o & o & 192 \\
\hline 27/3/2006 & 72 & 288 & 25.9 & 0.3 & 99 & o & o & o & o & 216 \\
\hline $28 / 3 / 2006$ & 73 & 312 & 24.6 & 15 & 99 & o & o & o & o & 240 \\
\hline $29 / 3 / 2006$ & 74 & 336 & 26.1 & 4.3 & 99 & o & o & o & o & 264 \\
\hline $30 / 3 / 2006$ & 75 & 360 & 25.2 & 12.7 & 99 & o & o & o & o & 288 \\
\hline $31 / 3 / 2006$ & 76 & 384 & 24.2 & 31.8 & 99 & o & o & o & o & 312 \\
\hline $1 / 4 / 2006$ & 77 & 408 & 26.9 & o & 99 & o & o & o & o & 336 \\
\hline 2/4/2006 & 78 & 432 & 24.8 & 29 & 99 & o & o & o & o & 360 \\
\hline $3 / 4 / 2006$ & 79 & 456 & 25.2 & 2.5 & 99 & o & o & o & o & 384 \\
\hline 4/4/2006 & 80 & 480 & 25.1 & 0.5 & 99 & o & o & o & o & 408 \\
\hline $5 / 4 / 2006$ & 81 & 504 & $25 \cdot 7$ & 1.8 & 99 & o & o & o & o & 432 \\
\hline $6 / 4 / 2006$ & 82 & 528 & 26.2 & 11.4 & 99 & o & o & o & o & 456 \\
\hline 7/4/2006 & 83 & $55^{2}$ & 25.9 & 27.2 & 98 & o & o & o & o & 480 \\
\hline $8 / 4 / 2006$ & 84 & 576 & 25 & 3.6 & 97 & o & o & o & o & 504 \\
\hline $9 / 4 / 2006$ & 85 & 600 & $25 \cdot 3$ & 0.3 & 94 & o & o & o & o & 528 \\
\hline $10 / 4 / 2006$ & 86 & 624 & $25 \cdot 7$ & o & 91 & o & o & o & o & $55^{2}$ \\
\hline $11 / 4 / 2006$ & 87 & 648 & 23.9 & 0.5 & 88 & o & o & o & o & 576 \\
\hline $12 / 4 / 2006$ & 88 & 672 & 22.2 & o & 86 & o & o & o & o & 600 \\
\hline $13 / 4 / 2006$ & 89 & 696 & 25.6 & 3.6 & 88 & o & o & o & o & 624 \\
\hline $14 / 4 / 2006$ & 90 & 720 & 25.7 & 81.5 & 91 & o & o & o & o & 648 \\
\hline
\end{tabular}

Table 4. Relative abundance of adults Calliphoridae species collected in the less rainy season. Hemilucilia segmentaria (Fabricius): H.seg; Hemilucilia semidiaphana (Rondani): H.semi; Hemilucilia sousalopezi (Mello): H. Souz; Eumesembrinella besnoiti (Seguy): E.bes; Mesembrinella bellardiana Aldrich: M. bel; Paralucilia spp. Brauer \& Bergenstamm: Paralu; Cochliomyia macellaria (Fabricius): C.mace; Chrysomya albiceps (Wiedeman): C.alb, Chrysomya megacephala (Fabricius): C. mega, Chloroprocta idioidea (Robineau-Desvoidy): C.idi; Phaenicia eximia (Wiedemann): P. ex.

\begin{tabular}{|c|c|c|c|c|c|c|c|c|c|c|c|}
\hline Samples & H.seg & H.semi & H.souz & E.bes & M.bel & Paralu & C.mace & C.alb & C.mega & C.idi & P.ex \\
\hline 1 & 338 & 723 & 2 & 69 & 18 & 304 & 0 & o & 0 & 7 & 304 \\
\hline 2 & 561 & 1529 & o & 70 & 29 & 1542 & o & 26 & o & 13 & 19 \\
\hline 3 & 740 & 2067 & o & 53 & 20 & 1703 & o & 97 & o & 26 & 5 \\
\hline 4 & 261 & 1134 & o & 41 & 22 & 764 & 4 & 195 & 17 & 28 & 1 \\
\hline 5 & 68 & 404 & o & 34 & 21 & 55 & 1 & 60 & o & 29 & 1 \\
\hline 6 & 4 & 124 & o & 39 & 25 & 6 & o & 2 & o & 30 & 1 \\
\hline 7 & 1 & 68 & o & 30 & 15 & 1 & o & 3 & o & 7 & o \\
\hline 8 & 2 & 59 & o & 33 & 25 & 4 & o & 4 & o & 4 & o \\
\hline 9 & o & 37 & o & 9 & 2 & 1 & o & 10 & o & 8 & o \\
\hline 10 & o & 65 & o & 10 & 2 & 1 & o & 1 & o & 5 & o \\
\hline 11 & 2 & 95 & o & 37 & 4 & o & o & 4 & o & 109 & o \\
\hline 12 & o & 87 & o & 16 & 3 & o & o & o & o & 11 & o \\
\hline 13 & 1 & 83 & o & 10 & 3 & o & o & o & o & 1 & o \\
\hline 14 & o & 19 & o & 5 & 1 & o & o & o & o & 4 & o \\
\hline 15 & 1 & 44 & o & 7 & 2 & o & o & o & o & 1 & o \\
\hline 16 & 8 & 18 & o & 2 & 3 & o & o & o & o & 1 & o \\
\hline 17 & 24 & 3 & o & 1 & 1 & 1 & o & o & o & o & o \\
\hline 18 & 28 & 7 & o & 1 & o & o & o & o & o & 1 & o \\
\hline 19 & 13 & 3 & o & 4 & o & 1 & o & o & o & o & o \\
\hline 20 & 1 & 1 & o & 4 & 1 & o & o & o & o & 1 & o \\
\hline 21 & o & 4 & o & 6 & o & o & o & o & o & 1 & o \\
\hline
\end{tabular}


Table 4. Continuation...

\begin{tabular}{ccccccccccccccc}
\hline Samples & H.seg & H.semi & H.souz & E.bes & M.bel & Paralu & C.mace & C.alb & C.mega & C.idi & P.ex \\
\hline 22 & 1 & 2 & 0 & 4 & 0 & 1 & 0 & 0 & 3 & 0 & 0 \\
23 & 0 & 3 & 0 & 7 & 0 & 1 & 0 & 0 & 1 & 1 & 0 \\
24 & 0 & 5 & 0 & 4 & 0 & 0 & 0 & 0 & 0 & 2 & 0 \\
25 & 0 & 17 & 0 & 6 & 7 & 2 & 0 & 0 & 0 & 1 & 0 \\
26 & 0 & 15 & 0 & 4 & 8 & 1 & 0 & 0 & 0 & 0 & 0 \\
27 & 0 & 5 & 0 & 9 & 4 & 1 & 0 & 0 & 0 & 2 & 0 \\
28 & 0 & 7 & 0 & 3 & 6 & 0 & 0 & 0 & 1 & 0 & 0 \\
29 & 0 & 1 & 0 & 19 & 7 & 0 & 0 & 0 & 0 & 0 & 0 \\
30 & 0 & 0 & 0 & 21 & 7 & 0 & 0 & 0 & 3 & 1 \\
\hline
\end{tabular}

Table5. Relative abundance of adults Calliphoridae species collected in theintermediary period. Hemilucilia segmentaria (Fabricius): H.seg; Hemilucilia semidiaphana (Rondani): H.semi; Hemilucilia sousalopezi (Mello): H. Souz; Eumesembrinella besnoiti (Seguy): E.bes; Mesembrinella bellardiana Aldrich: M. bel; Paralucilia spp. Brauer \& Bergenstamm: Paralu; Cochliomyia macellaria (Fabricius): C.mace; Chrysomya albiceps (Wiedeman): C.alb, Chrysomya megacephala (Fabricius): C. mega, Chloroprocta idioidea (Robineau-Desvoidy): C.idi; Phaenicia eximia (Wiedemann): P. ex.

\begin{tabular}{|c|c|c|c|c|c|c|c|c|c|c|c|}
\hline Samples & H.seg & H.semi & H.souz & E.bes & M.bel & Paralu & C.mace & C.alb & C.mega & C.idi & P.ex \\
\hline 31 & 91 & 165 & o & 7 & 6 & 13 & o & 5 & o & o & 74 \\
\hline 32 & 393 & 635 & 0 & 21 & 30 & 375 & 28 & 260 & 6 & 1 & 8 \\
\hline 33 & 475 & 305 & 0 & 49 & 31 & 753 & 6 & 435 & 6 & 4 & 3 \\
\hline 34 & 415 & 627 & o & 77 & 35 & 555 & 7 & 427 & 17 & 27 & 2 \\
\hline 35 & 109 & 168 & o & 125 & 21 & 135 & o & 59 & o & 10 & 1 \\
\hline 36 & 42 & 167 & 0 & 47 & 25 & 39 & 1 & 27 & 0 & 3 & 0 \\
\hline 37 & 23 & 134 & 0 & 49 & 101 & 38 & 2 & 38 & o & 4 & o \\
\hline 38 & 11 & 224 & 0 & 27 & 11 & 42 & o & 52 & 1 & 1 & o \\
\hline 39 & 5 & 72 & o & 84 & 25 & 11 & o & 12 & o & 1 & 1 \\
\hline 40 & 6 & 118 & o & 17 & 5 & 1 & 1 & 15 & o & o & o \\
\hline 41 & 1 & 113 & 0 & 36 & 10 & 7 & o & 14 & o & 2 & 1 \\
\hline 42 & 2 & 85 & o & 29 & 3 & 6 & o & 85 & o & 1 & o \\
\hline 43 & 2 & 55 & o & 17 & 10 & 5 & o & 66 & o & o & o \\
\hline 44 & 2 & 78 & o & 13 & 12 & o & o & 20 & o & o & o \\
\hline 45 & 5 & 119 & 0 & 22 & 19 & 3 & 1 & 17 & 0 & 1 & 0 \\
\hline 46 & 13 & 45 & o & 165 & 56 & 4 & o & 3 & o & 1 & o \\
\hline 47 & 8 & 87 & o & 87 & 27 & 3 & o & 5 & o & 1 & o \\
\hline 48 & 6 & 88 & o & 96 & 17 & 10 & o & 12 & o & 1 & 1 \\
\hline 49 & 4 & 70 & o & 105 & 31 & 3 & 0 & 5 & 0 & 4 & 1 \\
\hline 50 & 1 & 11 & o & 53 & 29 & 2 & o & o & o & o & o \\
\hline 51 & o & 14 & o & 69 & 32 & o & o & o & o & 1 & o \\
\hline 52 & 1 & 4 & o & 38 & 21 & o & o & o & o & o & o \\
\hline 53 & o & 17 & o & 70 & 10 & 1 & o & 1 & o & o & o \\
\hline 54 & o & 13 & o & 37 & 10 & 1 & o & o & o & o & o \\
\hline 55 & o & 9 & o & 23 & 3 & o & o & 1 & o & o & o \\
\hline 56 & o & 7 & o & 16 & 13 & 1 & o & 1 & o & o & o \\
\hline 57 & o & 7 & o & 46 & 14 & o & o & o & o & 10 & o \\
\hline 58 & 1 & 11 & o & 11 & 3 & 1 & o & 1 & o & o & o \\
\hline 59 & 3 & 19 & o & 61 & 10 & 1 & o & 1 & o & 3 & o \\
\hline 60 & 1 & 7 & 0 & 47 & 20 & 0 & o & o & 0 & 4 & o \\
\hline
\end{tabular}

Table 6. Relative abundance of adults Calliphoridae species collected in the rainy season. Hemilucilia segmentaria (Fabricius): H.seg; Hemilucilia semidiaphana (Rondani): H.semi; Hemilucilia sousalopezi (Mello): H. Souz; Eumesembrinella besnoiti (Seguy): E.bes; Mesembrinella bellardiana Aldrich: M. bel; Paralucilia spp. Brauer \& Bergenstamm: Paralu; Cochliomyia macellaria (Fabricius): C.mace; Chrysomya albiceps (Wiedeman): C.alb, Chrysomya megacephala (Fabricius): C. mega, Chloroprocta idioidea (Robineau-Desvoidy): C.idi; Phaenicia eximia (Wiedemann): P. ex.

\begin{tabular}{|c|c|c|c|c|c|c|c|c|c|c|c|}
\hline Samples & H.seg & H.semi & H.souz & E.bes & M.bel & Paralu & C.mace & C.alb & C.mega & C.idi & P.ex \\
\hline 61 & 436 & 229 & o & 153 & 67 & 27 & o & 12 & o & 4 & 232 \\
\hline 62 & 744 & 625 & o & 218 & 108 & 50 & 1 & 37 & o & 31 & 86 \\
\hline 63 & 669 & 637 & o & 109 & 43 & 395 & o & 104 & o & 28 & 10 \\
\hline 64 & 308 & 421 & o & 102 & 30 & 168 & o & 147 & o & 30 & 1 \\
\hline 65 & 195 & 88 & o & 154 & 58 & 54 & o & 28 & o & 23 & 3 \\
\hline 66 & 120 & 136 & o & 176 & 30 & 23 & o & 7 & o & 10 & 4 \\
\hline 67 & 34 & 69 & o & 108 & 23 & 2 & o & 1 & o & 6 & 1 \\
\hline 68 & 10 & 52 & o & 90 & 33 & 1 & o & o & o & 2 & o \\
\hline
\end{tabular}


Table 6. Continuation...

\begin{tabular}{|c|c|c|c|c|c|c|c|c|c|c|c|}
\hline Samples & H.seg & H.semi & H.souz & E.bes & M.bel & Paralu & C.mace & C.alb & C.mega & C.idi & P.ex \\
\hline 69 & 43 & 78 & o & 135 & 71 & 4 & o & o & o & 16 & 2 \\
\hline 70 & 11 & 32 & o & 62 & 17 & o & o & 1 & o & 3 & 2 \\
\hline 71 & 12 & 36 & o & 52 & 14 & o & o & o & o & 1 & o \\
\hline 72 & 3 & 10 & 0 & 36 & 24 & o & o & o & 0 & o & o \\
\hline 73 & 17 & 5 & o & 36 & 24 & o & o & o & o & 2 & o \\
\hline 74 & 1 & 17 & o & 56 & 17 & o & o & o & o & 1 & o \\
\hline 75 & 4 & 14 & o & 42 & 13 & o & o & o & o & 1 & o \\
\hline 76 & 6 & 44 & o & 65 & 28 & o & o & o & o & 6 & o \\
\hline 77 & 2 & 26 & o & 39 & o & 1 & o & o & o & o & o \\
\hline 78 & 4 & 24 & o & 68 & 23 & 1 & o & o & o & 4 & o \\
\hline 79 & 1 & 3 & o & 25 & 11 & 1 & o & o & o & 4 & o \\
\hline 80 & 4 & 3 & o & 24 & 7 & o & o & o & 0 & 2 & o \\
\hline 81 & 2 & 3 & o & 28 & 10 & o & o & o & o & 3 & o \\
\hline 82 & 9 & 32 & o & 52 & 9 & 1 & 0 & 1 & o & 5 & 1 \\
\hline 83 & 2 & 9 & o & 42 & 18 & o & o & o & o & o & o \\
\hline 84 & 2 & 7 & o & 41 & 16 & o & o & o & o & 3 & o \\
\hline 85 & 1 & 2 & o & 14 & 7 & o & o & o & o & o & o \\
\hline 86 & 3 & 2 & o & 15 & 6 & 0 & o & o & o & 3 & o \\
\hline 87 & 1 & 1 & o & 11 & 8 & o & o & o & o & 1 & o \\
\hline 88 & o & 3 & o & 6 & 4 & o & o & o & o & o & o \\
\hline 89 & o & 5 & o & 66 & 14 & 1 & o & o & o & 8 & o \\
\hline 90 & 3 & 4 & o & 60 & 10 & 1 & o & o & o & 20 & o \\
\hline
\end{tabular}

Relationship between the ordination of the composition and abundance of adult blowflies (NMDS axes) with the postmortem interval (PMI-24-720 hours) (Figures 10 and 11). To verify the influence of the PMI (temporality) in the sampling results, a simple linear regression was performed between the postmortem interval in hours (24-720 hours) in each period, and the ordination axes (NMDS1 and NMDS2) (Figures 11.12). For the NMDS1 axis the results revealed an inverse influence of this variable in the samples $(\mathrm{F}=156.544$, $\mathrm{df}$ $=1,88$ and $\mathrm{P}=0.001$ ). The regression between the NMDS2 axis and the postmortem interval in hours, also showed an inverse influence of this variable in the samples, although the degree of significance of the results was smaller $(\mathrm{F}=9.338, \mathrm{df}=1,88$ and $\mathrm{P}=$ 0.003.) This was expected because the NMDS2 axis is the result of randomly generated calculations of distance taken from the first axis data (NMDS1).

The influence of the stages of decomposition and its duration in the sampling results (Figure 12). The result of the simple discriminant analysis between the NMDS axes (dependent variables), the stages of decomposition and its duration converted into categories (independent variables) showed a strong influence of the stages and their duration on the outcome of samples (Wilks' lambda $=0,3168$; $\mathrm{GL}=24,85: \mathrm{F}=$ 16.3095; GL $=8,168, \mathrm{P}=0.0001$ ). The stages of decomposition fresh, bloated and decay are related to each other in the same way as the saponification stage is to skeletonization. The two circles on the left of the graphic include the first four decomposition stages, which were the most attractive and shared most of the richness and abundance of taxa. These results corroborate those generated by the direct ordination made by the NMDS. The other two circles are aligned from left to right with intersections between them, relating to the saponification and skeletonization stages. These two stages shared recurrence of taxa and secondary low peaks of abundance.
Inferences. The diversity of Calliphoridae was high, with 11 taxa collected. Not all have their biology studied in the Amazon environment. Only three taxa had their importance as forensic indicators proven, however all of the taxa have a potential for forensic studies.

The decomposition of a man-size pig model, with approximately $60 \mathrm{~kg}$, in the Amazon region's warm and moist climate, went through the same stages of decomposition determined for other regions with different climate, but the stages had a shorter time interval. Despite the heat and high humidity, the experiments showed that 30 days were not sufficient for the total decomposition of the models used.

The experiments performed at different times of the year, in three "periods" that differed mainly in relation to precipitation (less rainy season, transition period and rainy season) but had stable and prevalent high temperature and high humidity, showed little difference between them. The rainy season (with a slightly cooler temperature) did not negatively influence the composition and abundance of species of blowflies, nor prolonged the decomposition stages.

The experimental design used was efficient since, at the end of the 30 days of sampling and based on the photographs taken, the models covered by traps for adults apparently had more leftover soft tissue than the models used exclusively to capture immatures. In addition, multivariate analyses demonstrated the ecological relationship between the composition and abundance of species of blow flies and the variables: precipitation, IPM and decomposition stages. 


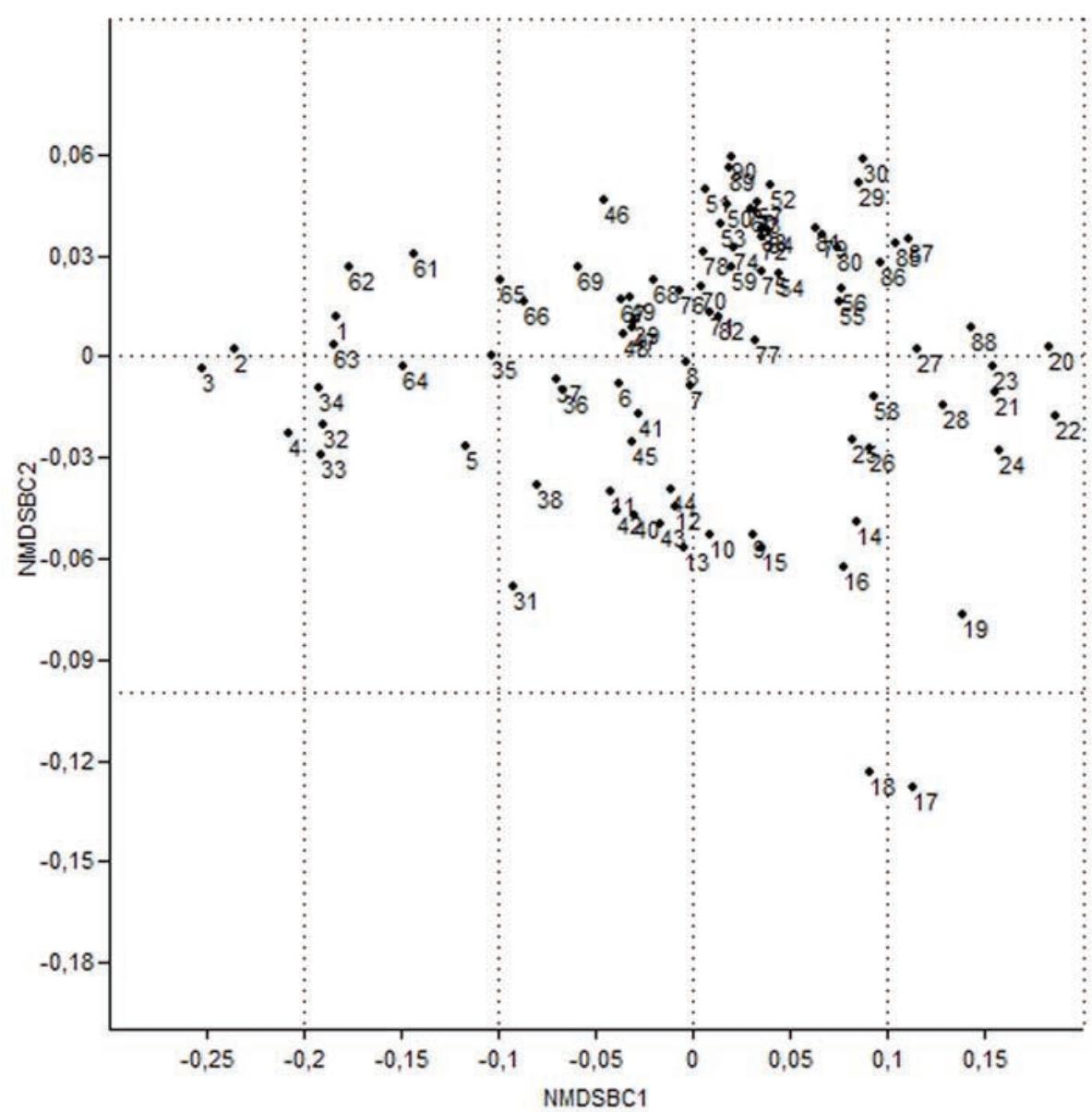

Figure 7. Scatter diagram of ordination by nonmetric multidimensional scaling (NMDS) based on Bray-Curtis distance in the three experiments: less rainy season (samples 1-30); transition period (samples 31-60) and the rainy season (samples 61-90).

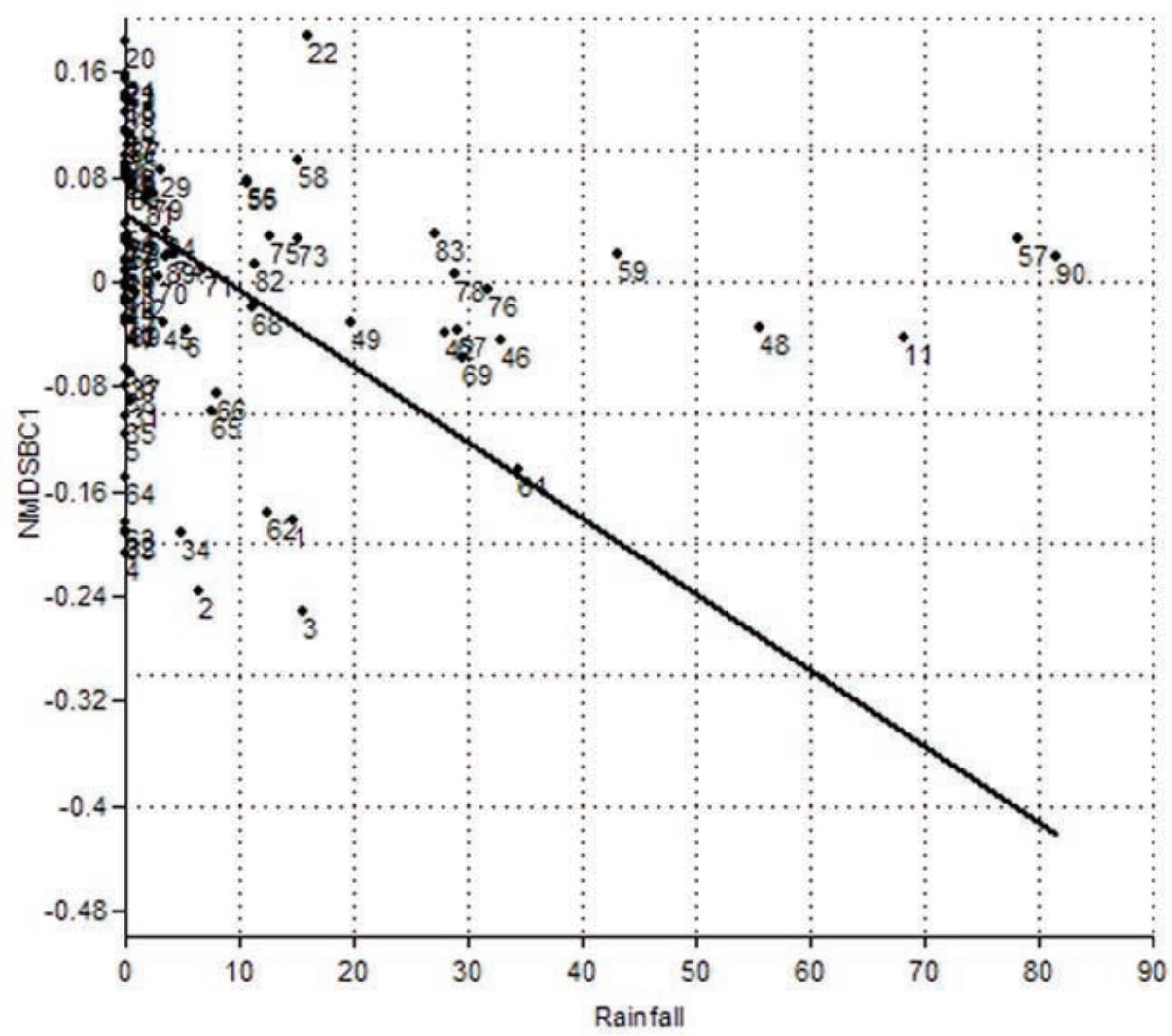

Figure 8. Scatter diagram of the linear regression between the axis (NMDS1) sort non-metric multidimensional scaling based on Bray-Curtis distance and rainfall in the three experiments: less rainy season (collections 1-30), transition period (samples 31-60) and the rainy season (samples 61-90). 


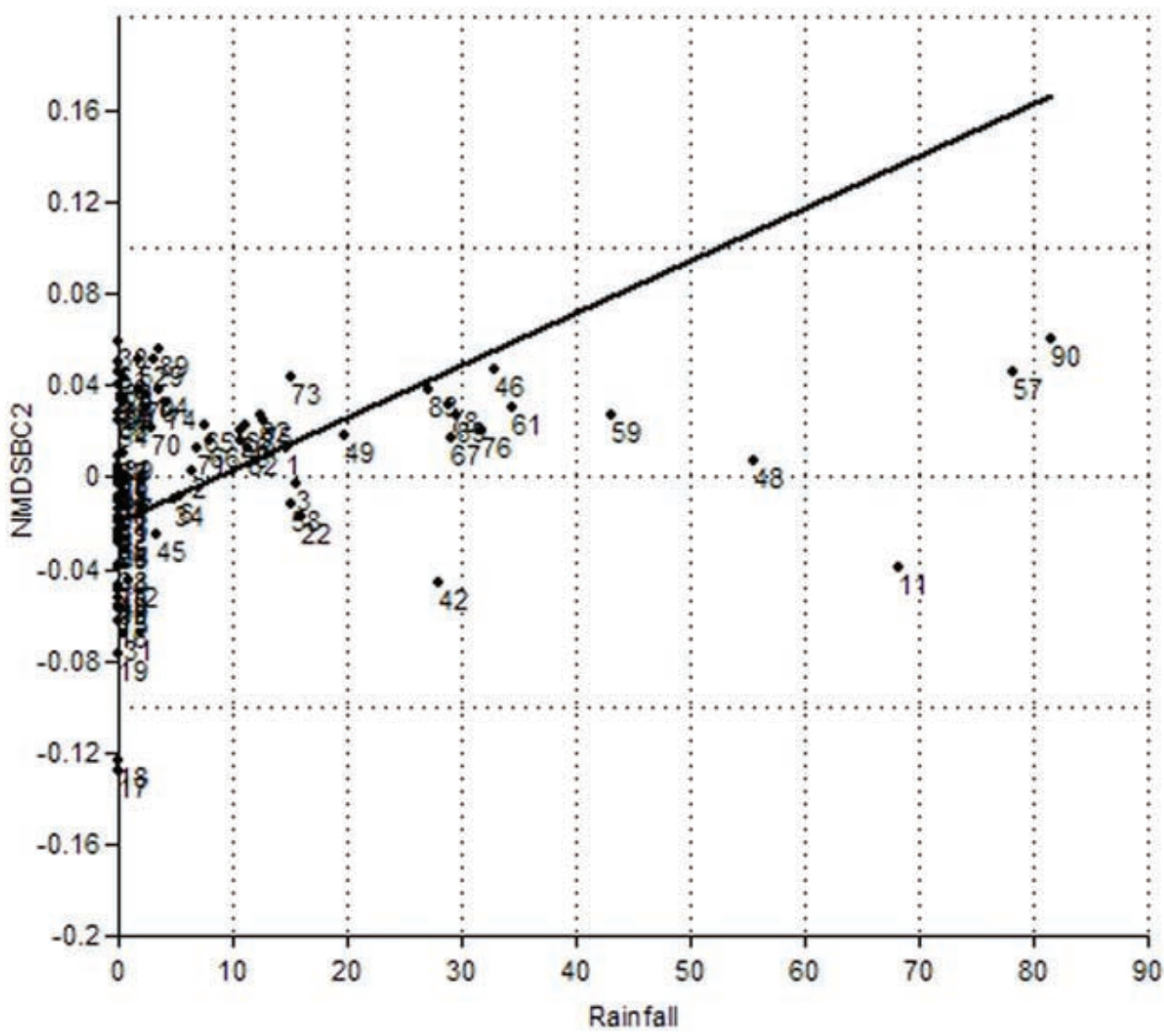

Figure 9. Scatter diagram of the linear regression between the axis (NMDS2) sort non-metric multidimensional scaling based on Bray-Curtis distance and the rainfall in three experiments: less rainy season (samples 1-30), transition period (samples 31-60) and the rainy season (samples 61-90).

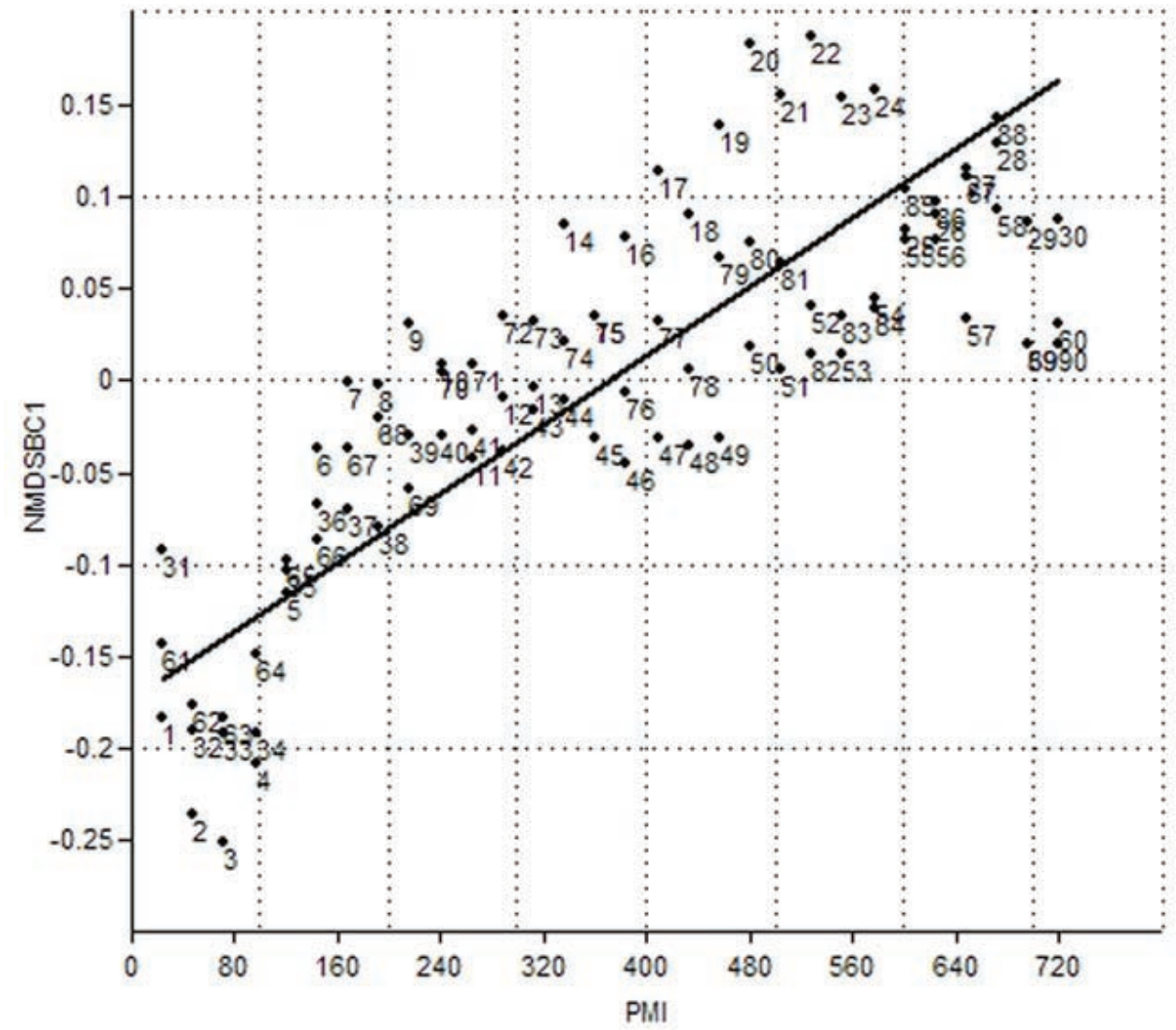

Figure 10. Scatter diagram of the linear regression between the axis (NMDS1) sort non-metric multidimensional scaling based on Bray-Curtis distance and postmortem interval in three experiments, less rainy season (collections 1-30), transition period (samples 31-60) and the rainy season (samples $61-90)$. 


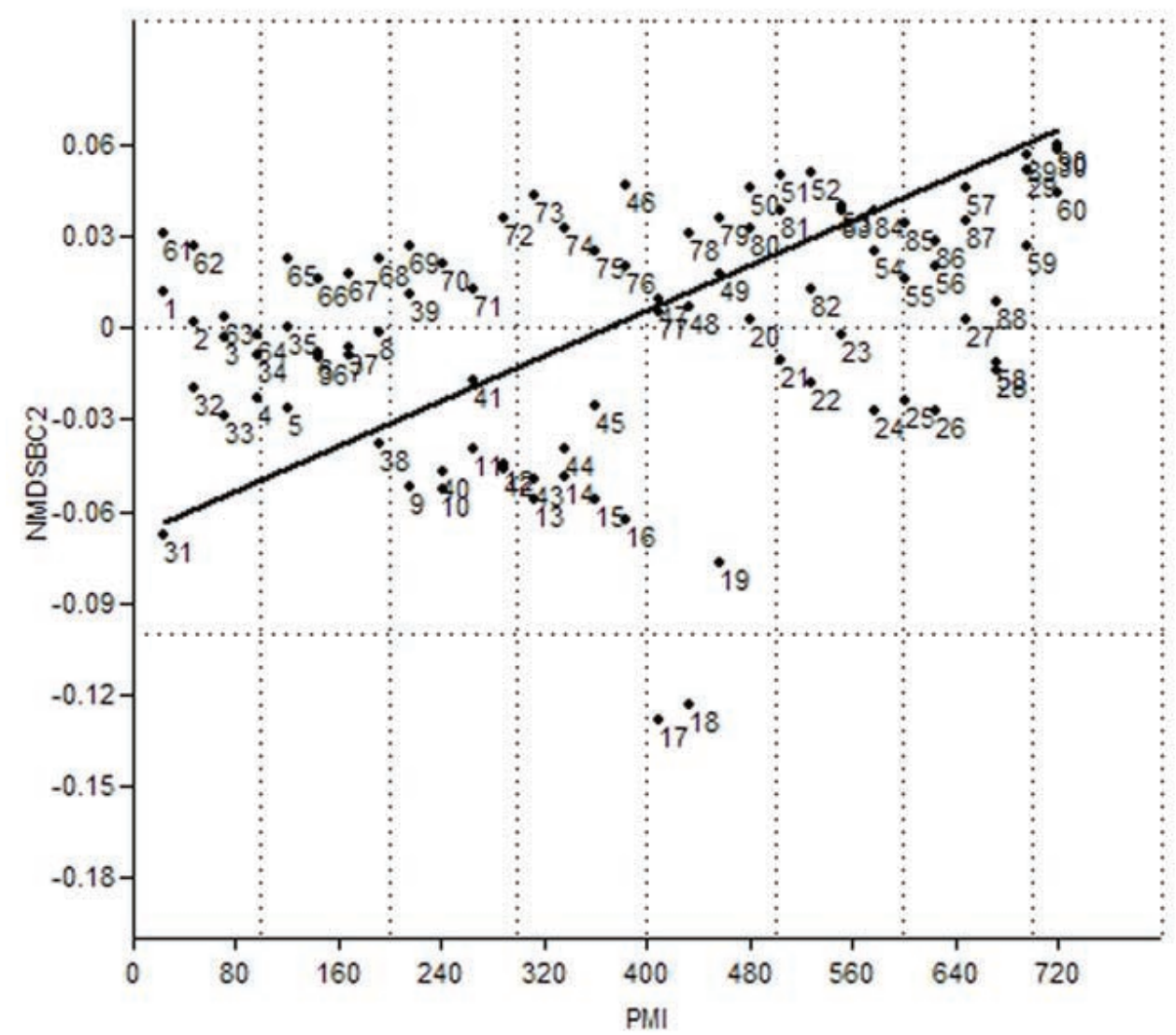

Figure 11. Scatter diagram of the linear regression between the axis (NMDS2) sort non-metric multidimensional scaling based on Bray-Curtis distance and postmortem interval in the three experiments: less rainy season (samples 1-30), period transition (samples 31-60) and the rainy season (samples 61-90).

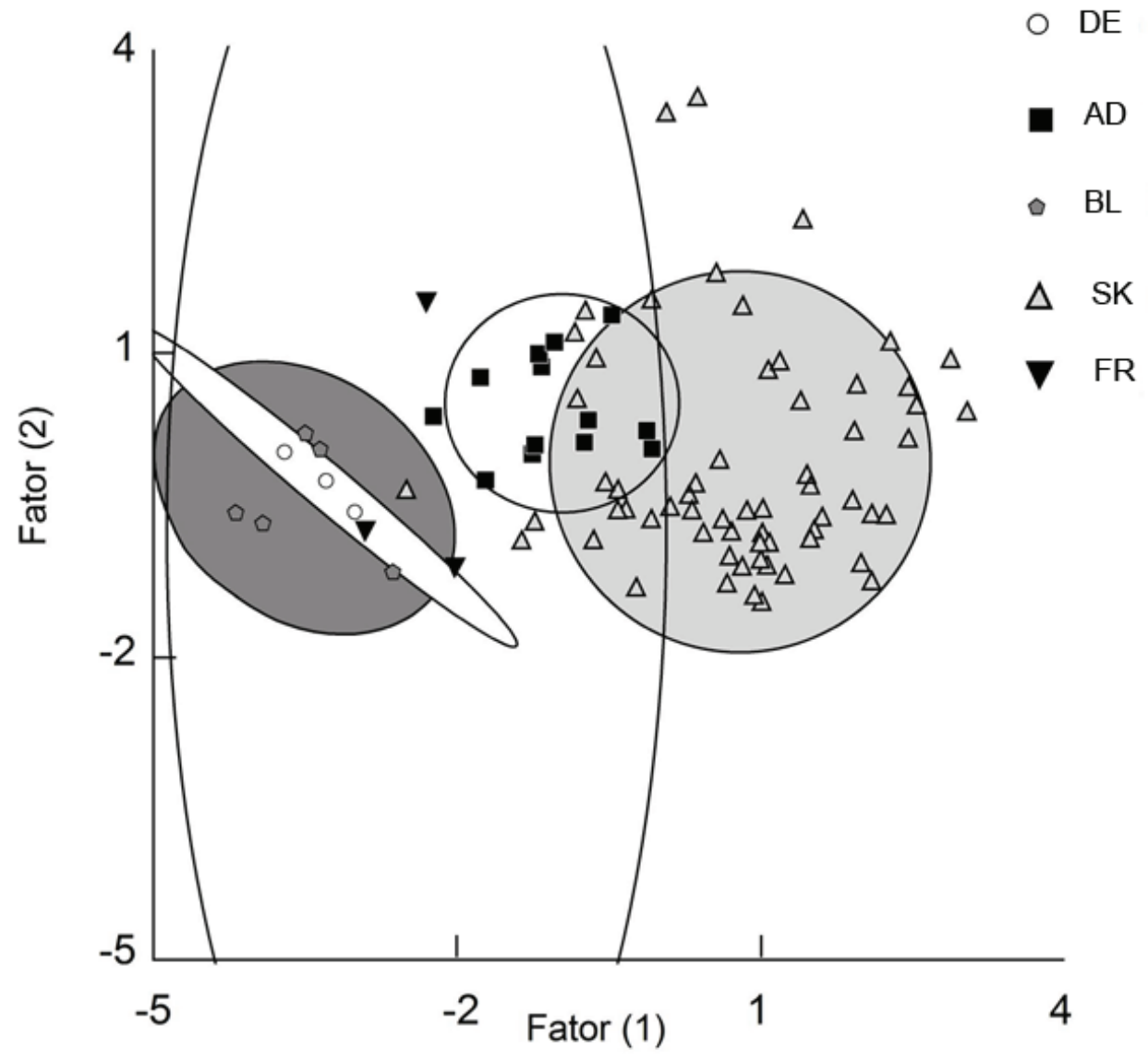

Figure 12. Scatter diagram of the simple discriminant analysis between the axis (NMDS1 and NMDS2) sort non-metric multidimensional scaling based on Bray-Curtis distance and the duration of decomposition stages converted in categorical variables in the three experiments: FR: fresh; BL: bloated; DE: decay; AD: adipocere and SK: skeletonized. 


\section{ACKOWLEDMENTS}

We would like to thank the Conselho Nacional de Desenvolvimento Científico e Tecnológico-CNPq, processes 141747/2004-8 (AUR), 52.1239/95-8 (JAR) and 308636/2007-4 (JRPL). We are also thankful to Instituto Nacional de Pesquisas da Amazônia (INPA) and Instituto Oswaldo Cruz for academic support. We are grateful for the help of Valzenir Antonio de Albuquerque and Anastácio Ribeiro Moreira (in memorian) from Divisão de Apoio e Suporte às Estações e Reservas do INPA-DSER. To M.Sc. Luciano Chaves Arantes, Instituto de Criminalística da Polícia Civil do Distrito Federal, Brasília, Brasil for the help in the classification of the decomposition stages. To Alexandre da Silva Filho (in memorian) by his logistical support trough all work. To Dra. Marta Wolff, Grupo de Entomología, Universidad de Antioquia, Medellín, Colombia by his revision of the manuscript. Finally, we would like to thank to Dr. Rubens Pinto de Mello of Instituto Oswaldo Cruz, Rio de Janeiro, Brasil or the help in determination of taxa sampled.

\section{REFERENCES}

Amendt, J., C.P. Campobasso, E. Gaudry, C. Reiter, H.N. LeBlanc \& M.J. R. Hall, 2007. Best practice in forensic entomology - standards and guidelines. International Journal of Legal Medicine 121: 90-104.

Barbosa, R.R., C.A. Mello-Patiu, A. Ururahy-Rodrigues., C.G. Barbosa \& M.M.C. Queiroz, 2010. Temporal distribuition of ten calyptrate dipteran species of medicolegal importance in Rio de Janeiro, Brasil. Memórias do Instituto Oswaldo Cruz, 105: 191-198.

Barros-Souza, A.S., R.L. Ferreira-Keppler \& D. Agra, 2012. Development Period of Forensic Importance Calliphoridae (Diptera: Brachycera) in a urban area under Natural Conditions in Manaus, Amazonas, Brazil. EntomoBrasilis, 5: 88-92.

Biavati, G.M., F.H.A. Santana \& J.R. Pujol-Luz, 2010. A Checklist of Calliphoridae Blowflies (Insecta, Diptera) Associated with a Pig Carrion in Central Brazil. Journal of Forensic Sciences, 55: 1603-1606.

Carvalho, L.M. \& A.X. Linhares, 2001. Seasonality of Insect succession and pig carcass decomposition in a Natural Forest in Southeastern Brazil. Journal of Forensic Sciences, 46: 604608.

Carvalho, L.M., P.J. Thyssen, A.X. Linhares. \& M.L. Goof, 2004. Observations on the Successional Patterns of Necrophagous Insects on a Pig Carcass in an Urban area of Southeastern Brasil. Aggrawal's Internet Journal of Forensic Medicine and Toxicology, 5: 33-39.

Carvalho, L.M., P.J.Thyssen, A.X. Linhares \& F.A. B.Palhares, 2000. A Checklist off Arthropods Associated with pig carrion and Human Corpses in Southeastern Brasil. Memórias do Instituto Oswaldo Cruz, 95: 135-138.

Catts, E.P. \& N.H. Haskell, editors. 1990. Entomology and death: a procedural guide. Clemsom, SC: Joyce's Print Shop, 184p.

Fraga, N.J. 2004. Comportamento de oviposição de adultos, tempo de desenvolvimento e morfologia dos imaturos de Hemilucilia segmentaria (Fabricius), H. semidiaphana (Rondani) e Lucilia eximia (Wiedemann) (Diptera: Calliphoridae) na Reserva Florestal Adolpho Ducke, Manaus, Brasil. Dissertação de Mestrado INPA-UFAM. 77p.

Kosmann, C., M.P. Macedo, T.A.F. Barbosa \& J.R. Pujol-Luz, 2011. Chrysomya albiceps (Wiedemann) and Hemilucilia segmentaria (Fabricius) (Diptera, Calliphoridae) used to estimate the postmortem interval in a forensic case in Minas Gerais, Brazil. Revista Brasileira de Entomologia, 55: 621623.

Magnusson, W.E. \& G.M. Mourão 2003. Estatística sem Matemática a ligação entre as Questões e as Análises. Londrina: Editora Planta. 126 p.

McCune, B. \& J.B. Grace, 2002. Analysis of Ecological Communities. Gleneden Beacch Oregon. 300 pp.
Mello, R.P., 1969. Contribuição ao estudo do gênero Myiolucilia Hall (Diptera, Calliphoridae). Studia Entomologica, 12: 297316.

Mello, R.P., 1972. Revisão das espécies do gênero Hemilucilia Brauer, 1895 (Diptera, Calliphoridae). Revista Brasileira de Biologia, 32: 539-554.

Mello, R.P., 1996. Revisão das espécies sul Americanas de Paralucilia Braurer \& Bergenstamm (Diptera: Calliphoridae). Entomologia y Vectores, 3: 137-143.

Mello, R.P., 2003. Chave para identificação das formas adultas das espécies da família Calliphoridae (Diptera, Brachycera, Cyclorrhapha) encontradas no Brasil. Entomologia e Vectores, 10: 255-268.

Mise, K.M., A. S.B. Sousa, C.M. Campos, R.L.F. Kepller. \& L.M. Almeida., 2010. Coleoptera associated with pig carcass exposed in a forest reserve, Manaus, Amazonas, Brazil. Biota Neotropica 10: http://www.biotaneotropica.org.br/v10n1/ pt/fullpaper?bno3110012010+en

Moura, M.O., C.J.B. Carvalho, \& E.M. A Monteiro-Filho, 1997. A preliminary Analysis of Insects of Medico-legal Importance in Curitiba, State of Paraná. Memórias do Instituto Oswaldo Cruz, 92: 269-274.

Oliveira-Costa, J., 2011. Entomologia Forense, quando os insetos são vestígios. Tratado de Perícias Criminalísticas. terceira edição. Campinas. Ed. Millenium, Campinas, Millenium, $3^{\text {a }}$ edição. 502p.

Oliveira-Costa, J. \& C.A. Mello-Patiu, 2004. Application of Forensic Entomology to estimate of the post mortem interval (PMI) in homicide investigations by the Rio de Janeiro Police Department in Brasil. Aggrawal's Internet Journal of Forensic Medicine and Toxcology, 5: 40-44.

Oliveira-da-Silva, A., R. Ale-Rocha \& J.A. Rafael, 2006. Bionomia de estágios imaturos de duas espécies de Peckia (Diptera, Sarcophagidae) em suíno em decomposição em área de floresta no norte do Brasil. Revista Brasileira de Entomologia, 50: 524-527.

Pujol-Luz, J.R., H. Marques, A. Ururahy-rodrigues, J.A. Rafael, F.H.A. Santana, L.C. Arantes \& R. Constantino, 2006. A Forensic Entomoloy case from the Amazon Rain Forest of Brazil. Journal of Forensic Sciences, 51: 1151-1153.

Pujol-Luz, J.R., P.A.C. Francez, A. Ururahy-Rodrigues \& R. Constantino, 2008. The Black Soldier-fly, Hermetia illucens (Diptera, Stratiomyidae), used to estimate the Postmortem Interval in a Case in Amapá State, Brazil. Journal of Forensic Sciences, 53: 476-478.

Rafael, J.A \& I.S. Gorayeb, 1982. Tabanidae (Diptera) da Amazônia I. Uma nova armadilha suspensa e primeiros registros de mutucas de copas de árvores. Acta Amazonica, 12: $232-236$.

Roquette-Pinto, E., 1908. Nota sobre a fauna cadavérica do Rio de Janeiro. Tribuna Médica, 21: 413-417.

Smith, K.G.V., 1986. A manual of forensic entomology. British Museum (Natural History) London. 205 p.

Stuart, B.H., L. Craft., S.L. Forbes, \& B.B. Dent, 2005. Studies of Adipocere Using Total Reflectance Infrared Spectroscopy. Forensic Science, Medicine, and Pathology, 1: 197-201.

Ururahy-Rodrigues, A., J.A. Rafael, J.R. Pujol-Luz, A.L. Henriques, M.M.C. Queiroz, R.R. Barbosa \& M.N. Baroni, 2010. Association of Oxelytrum cayennense (Silphidae, Coleoptera) with Pig Carcasses (Sus scrofa, Suidae) in Terra Firme Areas in Manaus, Amazonas, Brazil. EntomoBrasilis, 3: 45-48.

Ururahy-Rodrigues, A., J.A. Rafael, R.F. Wanderley, H. Marques \& J.R. Pujol-Luz, 2008. Coprophanaeus lancifer (Linnaeus, 1767) (Coleoptera, Scarabaeidae) activitymoves a man-size pig carcass: relevant data for forensic Taphonomy. Forensic Science International, 182: e19-e22.

Recebido em: 21/o4/2012

Aceito em: 25/11/2012

$* * * * * * * * *$ 


\section{Como citar este artigo:}

Ururahy-Rodrigues, A., J.A. Rafael \& J.R. Pujol-Luz, 2013. Temporal Distribution of Blowflies of Forensic importance (Diptera: Calliphoridae), in man-size Domestic Pigs Carcasses, in the Forest Reserve Adolpho Ducke, Manaus, Amazonas, Brazil. EntomoBrasilis, 6(1): 09-22.

Acessível em: http://www.periodico.ebras.bio.br/ojs/index.php/ebras/article/view/242. doi:12741/ebrasilis.v6i1.242
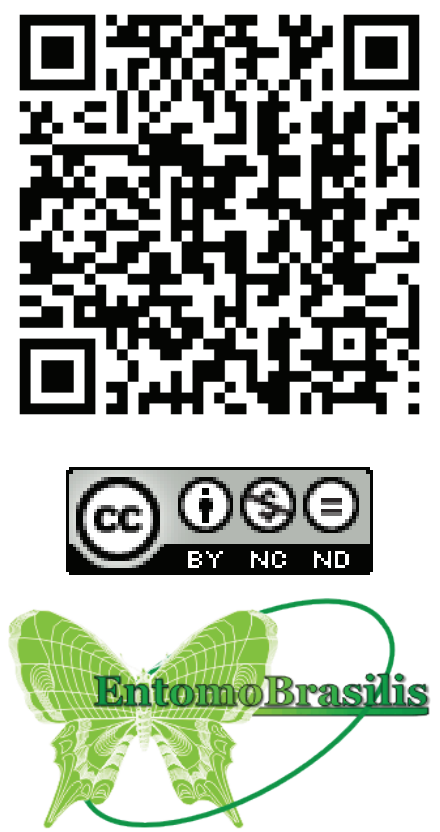